\title{
Employee Participation and Determination of Minimum Wage among Primary School Teachers in Osogbo, Osun State, Nigeria
}

\author{
Isiaka Kolawole Egbewole \\ Department of Public Administration, \\ Faculty of Management Sciences, \\ Federal University Oye-Ekiti, Ekiti State, Nigeria
}

Received: Jun. 4, 2020 Accepted: Jul. 2, 2020 Online published: Oct. 12, 2020

doi:10.5296/ijhrs.v10i4.17817ＵRL: https://doi.org/10.5296/ijhrs.v10i4.17817

\begin{abstract}
The study examined the effect of employee participation and determination of minimum wage among selected primary schools in Osogbo, Osun State Nigeria. Descriptive survey research designs were adopted for the study. The population of the study was 145 staff of the selected primary schools while taro yamane formula was used to determine 106 as the sample size. Questionnaire was used to elicit information from the respondents and single linear regression was used to analyze the collected data with the help of statistical package for social sciences (SPSS). The findings of the study revealed that (i) The correlation coefficient (R) equals $\left[\mathrm{r}(98)=.43^{* *}, \mathrm{p}<.01\right]$, indicates that the hypothesis two was not statistically supported by the result of the studies. (ii) The result showed further that age $(\beta=.21, t=4.26$, $\mathrm{P}<.01$; Educational status $(\beta=.15, \mathrm{t}=3.64, \mathrm{P}<.01)$, length of service $(\beta=.19, \mathrm{t}=4.03, \mathrm{P}<.01)$ and job status $(\beta=.22, \mathrm{t}=4.63, \mathrm{P}<.01)$ showed significantly independent prediction of minimum wage and employee participation among staff of selected primary schools. However, the result revealed that gender $(\beta=.02, \mathrm{t}=.04, \mathrm{p}<.05)$ and marital status $(\beta=.03$, $\mathrm{t}=.06, \mathrm{p}<.05$ ), did not show significantly independent prediction of minimum wage and employee participation. The study concluded that workers participation has negative effect on employees' job satisfaction, productivity, commitment, which can create comparative advantage for an organization. The study recommends that having established a gap currently existing on employee participation and minimum wage, it helps in motivating employers and employees at different sectors to encourage a proper minimum wage scale.
\end{abstract}

Keywords: minimum wages, employee participation, productivity, wage and salaries 


\section{Introduction}

Employee Participation in modern industrial organization encouraged employees to take responsibility for quality in respect of carrying out activities, which meet the requirements of their customers. It increases employees' commitment and improves the work performance. Employee participation emphasizes the want for collaboration amid corporation and employee, and for employees to participate in the decision making measures of management (Bendix, 2001). Employee Participation if implemented effectively in decision making, its benefits are wide ranging and it is a tool of employee motivation leading to a positive work attitude and high productivity (Uma, 2015). Employee participation includes the involvement of the employee in as many sides of his/her work existence as possible; this can occur either directly or indirectly in trade union, which might be the representatives of the employees (Bendix, 2001). It is extensively held that employee participation may also have an effect on an employee task pleasure, productiveness, commitment, that can create comparative gain for a business enterprise (Bhatti \& Qureshi, 2007). Effective enterprises have a culture that encourages worker involvement, since employees are willing to get involved within the choice making method, purpose setting and problem solving activities, which then results in higher worker performance (Bhatti \& Qureshi, 2007).

The participation of workers in decision making is concerned with shared decision making in work situation. Witte, 1980; Sagiee \& Aycon, (2003) supposed that managers should offer chances for participation of subordinates in decision making on the basis of their merits to the organization. Employee participation is known as a joint making decision between employee and employer in an organization. Noah (2008) realizes that it is the special form of delegation in which the subordinates gain greater control and freedom of choice with respect to bridging the communication gap between management and workers. More-so, it refers to the degree of employee involvement in a country's strategic planning activities.

There are two significant factors to determine the effect of minimum wage by the enforcement of the minimum wage laws, and the size of the formal and informal sector. There are several organizations where minimum wage are not enforced. The alarming issues of some firm without union to guide employee on how minimum wage can be realized in the organization will be addressed.

\section{Statement of the Problem}

Minimum wage issue cannot be overemphasized in our contemporary today. It often causes business enterprises untold hardship in terms of constant agitations. The squabble is that disbursing workforces a higher wage may lead to better production from the employee. If an employee gets a moderately higher wage, he/she may feel more enthusiastic and become trustworthy to the establishment. The hostile part of remuneration increase can be the increase in redundancy, increase in market rates, which can ultimately lead to general increase in the price of goods. This is a vivacious problem, which not only disquiets minimum wage workers, but also the business owners. The growing emphasis on all forms of flexibility in industry in response to competitive pressures, succeeding changes in work organization and the current administrative climate is reflected in the emerging models of 
participation.

In Nigeria today, government and private business owner has failed the employee by not fulfilling the negotiated minimum wage. These has raise to strike, conflicts and dispute, loss of employee morale and negative effect of employee performance.

\section{Research Hypotheses}

The below stated hypotheses shall be tested in the study

$\mathrm{H}_{1}$ : There is no significant relationship between employee participation and minimum wage.

$\mathrm{H}_{2}$ : There is no significant relationship between demographic factors on minimum wage and employee participation.

\section{Literature Review}

\section{Concept of Employee Participation}

Employee participation is referred to as the system, where the personnel obtain the rights to participate in the decision making processes regarding the issues, which are of concern to the personnel. These include, salaries and reimbursements, working environmental conditions, health and safety, well-being, job concerns, job responsibilities and rights and opportunities. Employee participation is a matter of providing opportunities to all the members of the organization to contribute effectively towards promoting welfare and goodwill. Better participation and greater responsibility in the decision making processes on the part of the employees will lead to development of loyalty, trust and confidence, and a sense of responsibility towards supervisors, managers and organization in general. Bendix, (2001) speculated that employee participation involves the involvement of the employee in as many facets of his/her work life as possible; this may occur either by direct or indirect means which are the representatives of the employees. It is widely believed that employee participation may affect an employee's job satisfaction, productivity, commitment, which can create comparative advantage for an organisation (Bhatti \& Qureshi, 2007).

\section{Forms of Employee Participation Direct Employee Participation}

Kester (2007), sight direct participation as decision made at the entry level of the organization. Direct participation usually encompasses that the juniors participate, speak for and by themselves about work or matters related to labor. It is observed as a process of job enhancement and enlargement where the worker is offered the possibility of extending the depth and width of his work tasks, but without any control over organisational planning or goal setting (Nel, 2005). This includes sharing of financial rewards, which result from increased performance to productivity; the provision of relevant information on the job consultation about changes that may affect the employee and personal involvement of employees in the decision making process (Nel, 2005).

\section{Indirect Employee Participation}

Indirect participation is a condition where workforces share in some or all decisions that are 
made in the workplace through their representatives known as trade union (Kester, 2007). Finnemore (2006), wrote that indirect participation of workers in decision making is one whereby workers participate through trade union activities to cub the unending battle between the management and the employee. The use of collective bargaining by Anstey (2004), where he noted that indirect form of employee participation in decision making is the most common form of employee participation in the globe today. Similarly, Bendix (2010) also make use of indirect form of employee participation in decision making, particularly because the process of collective bargaining allows trade union and employers' representatives to involve in the joint regulation of workplace-related issues, whilst they may jointly solve problems, which may arise.

\section{Forms of Employee Participation}

i. Informational Participation: The member of the joint committee shares certain information with the management such information are been kept within the members of the committee.

ii. Advisory Participation: Management takes advice from the labour representatives in formulating policies and strategies of the organization.

iii. Constructive Participation: The representatives of both employees and employers have the right to suggest methods and processes for bringing about improvements within the organizations.

iv. Joint Determination: All matters and administrative policies are decided by the committee member's i.e the Council of board consists of both labour and management.

v. Administrative Participation: Decisions are taken before it comes to the committee, but the implementation method of the decisions within reasonably given alternatives is left to be determined by the committee.

\section{Theoretical Review}

\section{The Wage Theory}

This theory was propounded by Adam Smith "Wealth of Nation" in 1776. This theory explained what determine the level of wage. This theory has gone through three stages of development since the middle ages.

i. The Just Wage: This was concocted by churchmen and given a moral favour to support the status it is a relic of static, from which both intellectual and natural historical interest, nevertheless, there are vestigial remnants of the just wage in some of the more advanced societies.

ii. The Subsistence Theory: This theory was originated from the physiocratic school of the French economists and was commonly accepted in the century. Human being desire to get as much and the master to give as little as possible. Both try to combine together to improve the bargain each in his favour. Wages suggest that wages usually tend to be kept down to the minimum possible level. This theory of wage is linked to the nation of population. 
iii. The Standard of Living Theory of Wages

This theory was established in the late $19^{\text {th }}$ century, a modified of the above subsistence theory was propounded by some writers, which may called as the standard of living theory of wages according to this theory, the wages are determined not by subsistence level but by the standard of living to which a class of labourers becomes habituated. The basis for this theory is that workers generally do not accept wages below their standard of living and high standard of living also increases their efficiency and hence, wages, in any Nations workers through their organization, with hold their supply so that wages may not fall below their standard of living.

\section{Empirical Review}

Ikechukwu and Chidinma, (2017) carried out a research on the effects of employee participation on minimum wage determination. This study focused on the effects of employee participation on minimum wage determination, with reference to the Nigerian Labour Congress.

The specific objectives are to: ascertain the mode and level of Nigerian Labour Congress members' participation in minimum wage determination, and examine the impact of employee participation in minimum wage determination on the performance of members of Nigerian Labour Congress. Furthermore, the result revealed that bargaining process, bringing low wages up to standard, eliminating unfair competition and advising government which are modes of participation in minimum wage determination are positive and significantly related to the performance of members of Nigerian Labour Congress. The researchers concluded that government in trying to reduce the pressure it gets from the Nigerian Labour congress should make positive response to the needs of Nigerian employees, and recommended that government should embark on and stick to adequate policy implementation as regards minimum wage determination.

Sabia and Burkhauser (2010) reviewed poverty effects of the increase in the states and federal minimum wage rates in the United States from $\$ 5.15$ per hour in 2003 to $\$ 5.85$ per hour in 2007 using a survey data and employing a panel regression. They went further to simulate the distributional effect of the then proposed increase in the minimum wage from $\$ 7.25$ per hour to in 2009 to $\$ 9.50$ per hour also using a population survey. Their findings showed no evidence that minimum wage increases between 2003 and 2007 reduced poverty rate. They also found that the proposed wage increase did not appropriately target the working poor, as only 11.3 per cent of workers who will benefit from the proposed wage increase lived in poor households. About 63.2 per cent of beneficiaries of minimum wage are secondary workers residing in households with income twice the poverty line, while 42.3 per cent of the beneficiaries lived in families with incomes three times the poverty line. It is noteworthy to point out that some studies have also established that minimum wage has poverty reducing effects. 


\section{Macrothink}

\section{Methodology}

This study employed descriptive survey research design. The population for this study consists of all staff of five selected primary schools in Olorunda Local Government area of Osun State. The primary schools selected are ADS Elementary Government School Sabo, Suraju Elementary School Otaefun, NUD Elementary School Oba Oke, RCM Elementary School Oba Oke and Agowande Elementary School Igbona. There are a total of 145 teachers in all the selected schools. The only instrument of data collection for this study was the questionnaire method. In other to select the respondent used for this study, the sample size was calculated using Guilford and Flruchter formula for estimating sample size:

$$
\frac{\mathrm{N}}{1+\mathrm{Q}^{2} \mathrm{~N}}
$$

Where $\mathrm{N}=$ Population size $=145$

$\mathrm{Q}=\mathrm{alfa}=0.05$

$$
\begin{array}{ccc}
\mathrm{N} & =145 \\
\frac{1+\mathrm{Q}^{2} \mathrm{~N}}{1+(0.05)^{2}(145)} & =106
\end{array}
$$

As a result, a sample of 106 respondents was chosen, only 100 questionnaire were filled and used for this study.

Data Presentation and Analysis

Table 1. Analysis of Response Rate

\begin{tabular}{lccc}
\hline Questionnaire & Respondents & Percentage & $(\%)$ \\
\hline Returned & 100 & 94.0 & \\
Not Returned & 6 & 6 & \\
Total Distributed & 106 & 100 & \\
\hline
\end{tabular}

Source: Field Survey, 2020

Frequency Distribution of Respondents'Socio-Demographic Characteristics

The frequency distribution of the socio-demographic characteristics of respondents are presented in this section below

Table 2. Distribution of Respondents by Gender

\begin{tabular}{|l|l|l|l|l|}
\hline Gender & $\mathrm{N}$ & Percentage (\%) & Valid percentage & $\begin{array}{l}\text { Cumulative } \\
\text { percentage }\end{array}$ \\
\hline Male & 43 & 43 & 43.0 & 43.0 \\
Female & 57 & 57 & 57.0 & 100 \\
\hline Total & 100 & 100 & & \\
\hline
\end{tabular}


Source: Author's Fieldwork, 2020

The result in table 2 above reveals that 43 (43\%) of the respondents were male while 57 (57\%) were female.

Table 3. Distribution of Respondents by Age Group

\begin{tabular}{|l|l|l|l|l|}
\hline Age Group & N & Percentage $(\%)$ & Valid percentage & $\begin{array}{l}\text { Cumulative } \\
\text { percentage }\end{array}$ \\
\hline $21-30$ years & 22 & 22 & 22.0 & 22.0 \\
\hline $31-40$ years & 25 & 25 & 25.0 & 47.0 \\
\hline $41-50$ years years and & 26 & 26 & 26.0 & 73.0 \\
\hline $\begin{array}{l}51 \text { above } \\
\text { Total }\end{array}$ & 27 & 27.0 & 100 \\
\hline
\end{tabular}

Source: Author's Fieldwork, 2020

The result in table 3 above reveals that $22(22 \%)$ of the respondents were within age group 21-30 years; 25 (25\%) were within age bracket 31-40 years; 26(26\%) of the respondents were within age bracket $41-50$ years. while $27(27 \%)$ of the respondents were within age bracket 51 years and above.

Table 4. Distribution of Respondents by Marital Status

\begin{tabular}{|l|l|l|l|l|}
\hline Marital Status & N & Percentage (\%) & $\begin{array}{l}\text { Valid } \\
\text { percentage }\end{array}$ & $\begin{array}{l}\text { Cumulative } \\
\text { percentage }\end{array}$ \\
\hline Single & 33 & 33 & 33.0 & 33.0 \\
\hline Married & 59 & 59 & 59.0 & 92.0 \\
\hline Divorced & 2 & 2 & 2.0 & 94.0 \\
\hline Separated & 4 & 4 & 4.0 & 98.0 \\
\hline Widowed/widow & 2 & 2 & 2.0 & 100 \\
\hline Total & 100 & 100 & & \\
\hline
\end{tabular}

Source: Author's Fieldwork, 2020

The result in table 4 above revealed that 33 (33\%) of the respondents were single; 59 (59\%) were married; $2(2 \%)$ of the respondents were divorced, $4(4 \%)$ of the respondents were separate while $2(2 \%)$ of the respondents were widowers/widows.

Table 5. Distribution of Respondents by Highest Educational Qualification

\begin{tabular}{|l|l|l|l|l|}
\hline Educational Background & $\mathrm{N}$ & Percentage $(\%)$ & $\begin{array}{l}\text { Valid } \\
\text { percentage }\end{array}$ & $\begin{array}{l}\text { Cumulative } \\
\text { percentage }\end{array}$ \\
\hline SSCE/GCE/NABTEB & 14 & 14 & 14.0 & 14.0 \\
\hline ND/A'Level/NCE & 27 & 27 & 27.0 & 41.0 \\
\hline B.Sc/HND & 50 & 50 & 50.0 & 91.0 \\
\hline
\end{tabular}


MA/M.Sc \& Above

TOTAL

\begin{tabular}{|l|l|l|}
\hline 9 & 9 \\
\hline 100 & 10 \\
\hline
\end{tabular}

\begin{tabular}{l|l}
9 & 9.0 \\
\hline 100 &
\end{tabular}

100

Source: Author's Fieldwork, 2020

The result in table 5 above reveals that 14(14\%) of the respondents were holders of

SSCE/GCE/NABTEB; 27(27\%) were holders of ND/A'Level/NCE; 20(20\%) were holders of B.Sc/HND, 50(50\%) while 9(9\%) were holders of MA/M.Sc \& Above.

Table 6. Distribution of Respondents by Length of service

\begin{tabular}{|l|l|l|l|l|}
\hline Length of Service & Frequency & Percent & $\begin{array}{l}\text { Valid } \\
\text { percentage }\end{array}$ & $\begin{array}{l}\text { Cumulative } \\
\text { percentage }\end{array}$ \\
\hline $0-5$ years & 14 & 14 & 14.0 & 14.0 \\
$6-10$ years & 26 & 26 & 26.0 & 40.0 \\
$11-15$ years & 34 & 34 & 34.0 & 74.0 \\
21 years and above & 26 & 26 & 26.0 & 100 \\
\hline Total & 100 & 100 & & \\
\hline
\end{tabular}

Source: Author's Fieldwork, 2020

The result in table 6 above reveals that $14(14.0 \%)$ of the respondents had length of service within $0-5$ years; 26 (26.0\%) of the respondents are under 6-10 years of service while 11-15 $(34.0 \%)$ of respondents while of 21 years and above were $26(26.0 \%)$.

Table 7. Distribution of Respondents by Job Status

\begin{tabular}{|l|l|l|l|l|}
\hline Job Status & N & Percentage & Valid percentage & $\begin{array}{l}\text { Cumulative } \\
\text { percentage }\end{array}$ \\
\hline Junior Staff & 37 & 37 & 37.0 & 37.0 \\
\hline Intermediate staff & 29 & 29 & 29.0 & 66.0 \\
\hline Senior staff & 20 & 20 & 20.0 & 86.0 \\
\hline Top Management & 14 & 14 & 14.0 & 100 \\
\hline Total & 100 & 100 & & \\
\hline
\end{tabular}

Source: Author's Fieldwork, 2020

The result in table 7 above showed that 37 (37\%) of the respondents were junior Staff; 29 (29\%) were intermediate staff; $20(20 \%)$ were on senior staff while 14 (14\%) were on top Management staff.

\section{Hypothesis Testing}

Hypotheses One: There is no significant relationship between employee participation and minimum wage among selected primary schools in Olorunda Local Government, Osogbo, 
Osun

State.

Table 8. A Summary Table of Pearson, $r$ correlation showing the relationship between employee participation and minimum wage among selected primary schools in Olorunda local government, Oshogbo

\begin{tabular}{|c|c|c|c|c|c|c|}
\hline Variables & $\mathrm{N}$ & $X$ & $\mathrm{SD}$ & df & $\mathrm{R}$ & $\mathrm{P}$ \\
\hline $\begin{array}{l}\text { Employee } \\
\text { Participation }\end{array}$ & 100 & 43.63 & 11.26 & \multirow[t]{2}{*}{98} & \multirow[t]{2}{*}{$.43 * *$} & \multirow[t]{2}{*}{$<.01$} \\
\hline Minimum Wage & 100 & 46.14 & 12.37 & & & \\
\hline
\end{tabular}

Source: Author's Fieldwork, 2020

The result in table 8 above reveals that there was a significant and positive relationship between employee participation and determination minimum wage among selected primary schools in Olorunda Local Government, Osogbo [r (98)=.43**, $\mathrm{p}<.01]$. Therefore, the hypothesis one was not supported by the result of the study.

Hypotheses Three: There is no significant relationship between demographic factors on minimum wage and employee participation among selected primary schools in Olorunda Local Government Osogbo, Osun State.

Table 9. A Summary Table of Multiple Regression of showing the independent and joint prediction of determination of minimum wage and employee participation by socio demographic factors (i.e gender, age, educational status, marital status and length of service and job status)

\begin{tabular}{|c|c|c|c|c|c|c|}
\hline Predictors & $\mathrm{B}$ & $\mathrm{T}$ & $\mathrm{P}$ & $\mathrm{F}$ & $\mathrm{P}$ & $\mathrm{R}^{2}$ \\
\hline Gender & .02 & 1.04 & $>.05$ & \multirow{6}{*}{37.49} & \multirow{6}{*}{$<.01$} & \multirow{5}{*}{.41} \\
\hline Age & .21 & 4.26 & $<.01$ & & & \\
\hline $\begin{array}{l}\text { Educational } \\
\text { Status }\end{array}$ & .15 & 3.64 & $<.01$ & & & \\
\hline Marital status & .03 & .06 & $>.05$ & & & \\
\hline $\begin{array}{ll}\text { Length } & \text { of } \\
\text { Service } & \end{array}$ & .19 & 4.03 & $<.01$ & & & \\
\hline Job Status & .22 & 4.63 & $<.01$ & & & \\
\hline
\end{tabular}

Source: Author's Fieldwork, 2020

The result in table 9 above showed that the socio - demographic factors of gender, age, educational status, marital status, length of service and job status showed significantly joint prediction of determination of minimum wage and employee participation $[\mathrm{F}=37.49, \mathrm{p}<.01$; $\left.\mathrm{R}^{2}=.41\right]$.

The result showed further that age $(\beta=.21, \mathrm{t}=4.26, \mathrm{P}<.01$; Educational status $(\beta=.15, \mathrm{t}=3.64$, $\mathrm{P}<.01)$, length of service $(\beta=.19, \mathrm{t}=4.03, \mathrm{P}<.01)$ and job status $(\beta=.22, \mathrm{t}=4.63, \mathrm{P}<.01)$ 
showed significantly independent prediction of minimum wage determination and employee participation among staff of selected primary schools. However, the result revealed that gender $(\beta=.02, \mathrm{t}=.04, \mathrm{p}<.05)$ and marital status $(\beta=.03, \mathrm{t}=.06, \mathrm{p}<.05)$, did not show significantly independent prediction of determination of minimum wage and employee participation.

\section{Discussion of Findings}

The first hypothesis revealed that there is no significant relationship between employee participation and determination of minimum wage and was rejected. The hypotheses were tested by Pearson Product Moment correlation and the findings showed that there was a significant and positive relationship between employee participation and minimum wage determination among selected primary schools in Olorunda Local Government, Osogbo. It is widely believed that employee participation may affect an employee's job satisfaction, productivity, commitment, which can create comparative advantage for an organisation (Bhatti \& Qureshi, 2007).

The second hypothesis which stated that there is no significant relationship between demographic factors on minimum wage and employee participation, was rejected independent prediction of determination of minimum wage. Efficient and effective internal communication, which is vital for an organisation can only be achieved by engaging employees in decision making.

The third hypothesis also tested that socio - demographic factors of gender, age, educational status, marital status, length of service and job status showed significantly joint prediction of determination of minimum wage and employee participation. Finnemore (2006) has explained that indirect participation of workers in decision making is one whereby workers participate through trade union activities to cub the unending battle between the management and the employee.

\section{Conclusion and Recommendation}

The study concluded that there is significant contribution of employee participation on minimum wage determination and it was also revealed that there was a significant positive relationship between demographic factors on employee participation on minimum wage determination. It was further revealed from the study that, Socio - demographic factors of gender, age, educational status, marital status, length of service and job status showed significantly joint prediction of employee participation and minimum wage determination among selected primary schools in Olorunda Local Government, Osogbo.

The study recommends that having established a gap currently existing on employee participation and minimum wage, it helps in motivating employers and employees at different sectors to encourage a proper minimum wage scale. Not only will the study have impact on organizations in general but also to individuals charged with various responsibilities in these 
organizations.

\section{Reference}

Akerlof, \& Yellen. (1990). The fair wage-effort hypothesis and unemployment. Journal of Economics, 105(2), May 1990. https://doi.org/10.2307/2937787

Bendix, S. (2001). Industrial Relations in South Africa. 4th ed. Lansdowne: Juta.

Bhatti, K. K. \& Qureshi, M. T. (2007). Impact of employee participation on job satisfaction, employee commitment, and employee productivity. International Review of Business Research Papers, 3(2), 54-68.

Brewster, C., Croucher, R., Wood, G., \& Brookes, M. (2007). Collective and Individual Voice: Convergence in Europe?' International Journal of Human Resource Management, 18(7), 1246-1262. https://doi.org/10.1080/09585190701393582

Du Toit, D., Johann, M., Theron, J., \& Shane, G. (2010). Collective Bargaining in South Africa: Past, Present and Future. Cape Town: Juta.

Economic Policy Institute. (2014). Endorse Higher U.S. Minimum Wage. Lorraine Woellert. Washington Research Group. Washington.

Ikechukwu, D., \& Chidinma, C. K. (2017) Effects of employee participation on minimum wage determination: A Study of the Nigerian Labour Congress. IIARD International Journal of Economics and Business Management, 3(2).

Kester, G. (2007). Trade unions and workplace democracy in Africa: Contemporary Employment Relations Series. London: Ashgate Publishing.

Nel, P. S., Swanepoel, B. J., Kirsten, M., Erasmus, B. J., \& Tsabadi, M. J. (2005). South African Employment Relations: Theory and Practice. 5th ed. Pretoria: Van Schaik Publishers.

Newmark, D., \& Washer, W. L. (2010). Minimum Wages. ILR Review. Sage Publications. Sabia, J. and Burkhauser, R. (2010). Minimum wages and poverty: will a $\$ 9.50$ federal minimum wage really help the working poor? Southern Economic Journal, 76(3), 592-623.

Shelley, M. (2007). The Stakeholding Theory of Corporate Governance: Can it Deliver Upon its Promises? Centre For Employment And Labour Relations Law. Working Paper No.17.

The Economist. (2013). Minimum Wages. The Logical Floor-December 2013. The Economist. December 14, 2013. London. United Kingdom.

Uma, M. H. (2015). Employee Participation: A tool of Motivation and High Productivity: Pacific Business Review International, 8(3).

U.S. Bureau of the Census. (2015). 45 Million Americans Still Stuck Below Poverty Line: Census. Washington, DC: Government Press, Print.

Westhuizen, D. (2010). Culture, participative decision making and job satisfaction. 


\section{Macrothink}

International Journal of Human Resource Studies

ISSN 2162-3058 2020, Vol. 10, No. 4

Unpublished Master's Thesis, University of KwaZulu-Natal, Durban.

Windolf, P. (1993), 'Co-Determination and the Market for Corporate Control in the European Community', Economy and Society, 22(2), 137-158. https://doi.org/10.1080/03085149300000008

Zavodny, M. (2000). The Effect of the Minimum Wage on Employment and Hours. In Labor Economics, 7(6) (November), 729-50. https://doi.org/10.1016/S0927-5371(00)00021-X

\section{Copyright Disclaimer}

Copyright for this article is retained by the author(s), with first publication rights granted to the journal.

This is an open-access article distributed under the terms and conditions of the Creative Commons Attribution license (http://creativecommons.org/licenses/by/4.0/). 